\title{
RESEARCH PAPER \\ Side effects of the natural pesticide Spinosad (GF-120 Formulation) on Eretmocerus paulistus (Hymenoptera: Aphelinidae), a parasitoid of the whitefly Aleurothrixus floccosus (Hemiptera: Aleyrodidae), under laboratory conditions
}

\author{
Víctor Tello ${ }^{1}$, Luis Díaz ${ }^{2}$ and Matías Sánchez ${ }^{1}$ \\ ${ }^{1}$ Facultad de Recursos Naturales Renovables, Universidad Arturo Prat. Avenida Arturo Prat 2120, Casilla \\ 121, Iquique, Chile. \\ ${ }^{2}$ Servicio Agrícola y Ganadero. Ministerio de Agricultura. Orella 440, Iquique, Chile.
}

\begin{abstract}
V. Tello, L. Díaz, and M. Sánchez. 2013. Side effects of the natural pesticide Spinosad (GF120 Formulation) on Eretmocerus paulistus (Hymenoptera: Aphelinidae), a parasitoid of the whitefly Aleurothrixus floccosus (Hemiptera: Aleyrodidae), under laboratory conditions. Cien. Inv. Agr. 40(2):407-417. The side effects of the insecticide GF-120 NF 0.02 Naturalyte $\mathrm{CB} \otimes$ were evaluated on adults of Eretmocerus paulistus Hempel, a parasitoid of Aleurothrixus floccosus (Maskell) in citrus orchards of northern Chile. $\mathrm{LC}_{50}$ and $\mathrm{LC}_{90}$ were determined by applying the insecticide using a Potter tower in decreasing doses from 0.96 to 0.1 $\mathrm{mg}$ a.i. $\mathrm{L}^{-1}$ (corresponding to $1 \%$ to $0.1 \%$ of the recommended dose, respectively). After $24 \mathrm{~h}$ of exposure, the results were fitted to a probit model, and the $\mathrm{LC}_{50}$ and $\mathrm{LC}_{90}$ were estimated at 0.21 and $0.79 \mathrm{mg}$ a.i. $\mathrm{L}^{-1}$, respectively. In feeding tests and evaluation of the toxic effect of dry residues of GF-120, it was determined that a high percentage of mortality $(100 \%)$ was obtained using a combination of $24.0 \mathrm{mg}$ a.i. $\mathrm{L}^{-1} \mathrm{x}$ residues at 1 hour drying time. Residues at $96 \mathrm{~h}$ (4 days) drying time with concentrations of 38.4 or $24.0 \mathrm{mg}$ a.i. $\mathrm{L}^{-1}$ caused mortalities over $60 \%$. According to the classification of the IOBC (International Organization for Biological and Integrated Control of Noxious Animals and Plants) the manufacturer's recommended concentration of $96 \mathrm{mg}$ a.i. $\mathrm{L}^{-1}$ was level 4, which is harmful (>99\%), as GF-120 concentrations can range from 0.77 to $72 \mathrm{mg}$ a.i. $\mathrm{L}^{-1}$. The GF-120 residues applied on inert surfaces were harmful to E. paulistus with a high mortality rate under laboratory conditions. Field studies are needed to validate these results by evaluating parasitoid populations in insecticide-treated and untreated areas.
\end{abstract}

Key words: Bioassays, insect parasitoids, natural pesticide, residual effect, side effects, toxicity.

\section{Introduction}

Pesticides are designed to be toxic to target noxious organisms that cause damage to crops and economic losses. However, some active ingredients can be harmful to the environment and to

Received June 25, 2012. Accepted February 24, 2013. Corresponding author: victor.tello@unap.cl non-target organisms (Delaplane, 2000) despite the efforts of research to develop and promote more selective and ecologically safer molecules (Schmutterer 1990; James et al., 1993; Thomson et al., 2000; Ishaaya et al., 2011).

The use of pesticides to control pests is validated by its many contributions to society. These contributions include the following: habitats 
previously uninhabitable because of vector-borne diseases are now habitable; crops are grown in large monocultures with minimal contamination by weeds and/or destruction by insects; and household pests can be easily eliminated (Rose et al., 1999; Waterfield and Zilberman, 2012). However, by their very nature, pesticides can also have deleterious effects. The indiscriminate use of synthetic pesticides in agriculture can adversely affect beneficial organisms, such as biocontrol agents and pollinators. This harmful effect on the activity of natural enemies may cause a resurgence of pests considered secondary or under natural control (e.g., Suma et al., 2009). These compounds contribute to the contamination of soil and aquatic environments (Martínez et al., 2004) and are also responsible for damaging human health, both in its preparation and during its application (Pértile et al., 2009).

This situation has forced the introduction of regulations for the production and application of these products, which have restricted the supply of pesticides and promoted research and development of pesticides based on natural products, such as spinosyns, avermectins, neem, rotenone and natural derivatives of pyrethrins (Dayan et al., 2009).

Spinosad is a natural insecticide derived by fermentation of the Actinomycete bacterium Saccharopolyspora spinosa Mertz \& Yao (Kirst, 2010; Miles et al., 2011). The active ingredient is composed of two metabolites, $85 \%$ spinosyn A and $15 \%$ spinosyn D (Orr et al., 2009). A bait was formulated to attract multiple fruit fly species and to use the minimum concentration of an environmentally compatible toxicant for ultra-low volume (2-4 L ha $\left.{ }^{-1}\right)$ application (Mangan et al., 2006). Spinosad has a novel mechanism of activity on nicotinic acetylcholine receptors, which would be the primary cause of death, most likely acting as an antagonist at the post-synaptic cholinergic ion channels and GABA-gated ion channels (Young et al., 2003). Spinosad is highly active when ingested or through contact and causes quick death in a wide range of insect pests, e.g., lepidoptera, diptera, thrips and foliage-feeding beetles (Biondi et al., 2012). Despite these promising experiences, spinosad has exhibited negative effects on the survival, longevity and fecundity of beneficial organisms under laboratory (Williams et al., 2003; Wang et al., 2005), greenhouse (Studebaker and Kring, 2003) and field conditions (Cisneros et al., 2002; Thomas and Mangan, 2005; Ruiz et $a l ., 2008)$. There is a large amount of information about spinosad characteristics and their effects on beneficial organisms; however, in Chile, this information is very limited. The Chilean studies include control of the following: California thrips, Frankliniella occidentalis (Pergande) (Vargas and Ubillo, 2005); Tuta absoluta (Meyrick) (Pozo, 2010); yellowjacket wasp, Vespula germanica (F.) (Ulloa et al., 2006); Cryptolaemus montrouzieri Mulsant and Acerophagus (= Pseudaphycus flavidulus) (Brethés) (Rojas, 2011); and Aphidius ervi (Haliday) (Araya et al., 2010). Considering this problem, the objective of this research was to evaluate, under laboratory conditions, the potential toxic effects of spinosad on Eretmocerus paulistus Hempel (Hymenoptera: Aphelinidae), a parasitoid of the woolly whitefly parasitoid in Pica, Tarapacá Region, Chile.

\section{Materials and methods}

The present study tested the insecticidal action of GF-120 NF Naturalyte 0.02 CB® (Dow AgroSciences), which is a mixture of the toxicant spinosad (spinosyn A and D), at a concentration of $240 \mathrm{mg}$ a.i. $\mathrm{L}^{-1}$, and a feeding attractant. A hydrolyzed protein is the lure component that attracts and induces feeding.

All tests were implemented during the months of April and May 2010. The determination of the $\mathrm{LC}_{50}$ and $\mathrm{LC}_{90}$ values was conducted at the Laboratory of Plant Health of Universidad Arturo Prat, located in Estación Experimental Canchones, Tamarugal Province, Tarapacá Region, Chile (20¹6'15.3” S, $\left.70^{\circ} 0746.6^{\prime \prime} \mathrm{W}\right)$, under experimental conditions 
of $25 \pm 5{ }^{\circ} \mathrm{C}, 30 \pm 10 \% \mathrm{RH}$ and a photoperiod of 16:8 (light:darkness).

For all studies, we used parasitoids collected from branches infested with Aleurothrixus floccosus (Maskell); the vegetal material was obtained from chemically untreated citrus orchards in Pica (20²9'12.40” S, 69¹9’34.14” W), Tamarugal Province, Tarapacá Region, Chile. The insecticide used for all tests corresponded to concentrate bait GF-120.

\section{Lethal concentrations $\left(L C_{50}\right.$ and $\left.L C_{90}\right)$}

Dilutions of GF-120 were applied using a Potter tower (Makers Burkards Manufacturing Co. Ltd., Rickmansworth, England) with a pressure of $55 \mathrm{KPa}$ (Vargas and Ubillo, 2001). The insects were exposed to a dry pesticide film applied on the internal surface of glass cages $\left(578 \mathrm{~cm}^{3}\right)$ made of six plates, which were joined externally using transparent adhesive tape to form a cube. The components of this container were attached externally using clear tape and parafilm (Viggiani and Tranfaglia, 1978; Suma et al., 2009).

The dose was based on manufacturer recommendations for the control of fruit flies (Mangan et al., 2006) but with further decreases to the concentration. The concentrations tested were $0.96,0.77,0.67,0.48,0.10$, and $0.00 \mathrm{mg}$ a.i. $\mathrm{L}^{-1}$, which corresponded to $1 \%, 0.8 \%, 0.7 \%, 0.5 \%$, $0.1 \%$, and $0.0 \%$ of the dose recommended by the manufacturer (DRM), respectively. Distilled water was used to dilute the insecticide treatment and the control. After applying the solution to the plates, the solution was allowed to dry for 1 $\mathrm{h}$ at room temperature to prevent mortality due to adherence of specimens to the surface (Iannacone and Lamas, 2003).

Branches were collected from citrus orchards, taken to the laboratory in plastic boxes at low temperature and placed in rearing chambers for the emergence of parasitoids. The emerged insects were aspirated to a glass vial and selected under a stereoscopic microscope at 40X magnification (Carl Zeiss Stemi SV6 model, Germany) inside the same container. Once selected, the specimens were released into the cubes through a hole of $3 \mathrm{~cm}$ diameter in one of its faces, and the hole was then sealed using absorbent paper and fixed with tape. The age of the insects was less than 24 hours since emergence; they were not given food or water.

The exposure time of the insects to the treatments, including the control, was $24 \mathrm{~h}$, and the evaluations were performed at 12 and $24 \mathrm{~h}$ from the introduction of the insect to the arenas for $30 \mathrm{~s}$ under the microscope. Parasitoids were considered dead if they could not walk when probed (Iannacone and Lamas, 2003; Yee and Alston, 2012).

Adult mortality feeding by E. paulistus (Nonchoice and residual tests)

To evaluate the combined effect of GF-120 concentrations [96 mg a.i. $\mathrm{L}^{-1}$ (DRM), $38.4 \mathrm{mg}$ a.i. $\mathrm{L}^{-1}(40 \% \mathrm{DRM})$ and $24.0 \mathrm{mg}$ a.i. $\mathrm{L}^{-1}$ (25\% DRM)] and the time on dry residues, nine treatments were applied with a factorial structure. For treatment application, the internal surfaces of glass vials were wet with a cotton swab containing the insecticide (Ruiz et al., 2008). The vials were allowed to dry for 1, 48 and 96 hours before introducing between 10 and 30 adults of $E$. paulistus less than $24 \mathrm{~h}$ old. The exposure time of insects to treatment was 12 h. Parasitoids were considered dead if they could not walk when probed.

\section{Design and statistical analysis}

Lethal concentrations. To determine the lethal concentrations, a completely randomized design was used with four replicates of the six treatments, including the control. A glass cube containing between 10 and 30 specimens was considered an experimental unit. To calculate the LC50 and 
LC90, the results were processed by probit analysis following the methodology used by Salazar and Araya (2001). The slopes of the regression between mortality (probit) and concentration (log) were analyzed using PROC PROBIT in SAS (SAS Institute Inc., Cary NC, USA, 2000) and applied according to Flores et al. (2007).

Feeding by E. paulistus. For feeding and residual tests, a completely randomized design was applied with a factorial structure, with nine treatments and four replicates, including the control. Treatments were formed by the interaction of two factors: GF-120 concentration and the pre-exposure time (dry residues).

Mortality percentages were corrected using Abbott's formula (Abbott, 1925) if mortality in the controls was greater than 5\% (Lagunes and Villanueva, 1999). The percentages were transformed using an arcsine transformation before evaluation (Zar, 2006). Tukey's test was used to determine which means $(\mathrm{P}<0.05)$ differed significantly from one another using PROC GLM (SAS Institute Inc., Cary NC, USA, 2000).

\section{Results and discussion}

\section{Determination of lethal concentrations}

At 1.0\% (0.96 mg a.i. $\left.\mathrm{L}^{-1}\right)$ of the recommended dose, the insecticide had an effect of $100 \%$ mortality on individuals after 12 and 24 hours of exposure ( $F=71.60$; d.f. $=5,17 ; \mathrm{P} \leq 0.001)$ (Table 1). After $24 \mathrm{~h}$, significant differences between treatments remained ( $\mathrm{F}=113.63$; d.f. $=5,17 ; \mathrm{P} \leq 0.001)$, registering mortality approaching $100 \%$ in the $0.67 \mathrm{mg}$ a.i. $\mathrm{L}^{-1}$ treatment. A dose corresponding to 0.096 $\mathrm{mg}$ of a.i. $\mathrm{L}^{-1}$ was not significantly different from the control in both tests. Mortality at 36 hours was $100 \%$ for all treatments (data not shown). According to Probit analysis (Table 2), the $\mathrm{LC}_{50}$ and $\mathrm{LC}_{90}$ for adults of $E$. paulistus were 0.49 (fiducial limits of 0.35 and 0.85 ) and 2.25 (fiducial limits of 1.17 and 10.27) $\mathrm{mg} \mathrm{a}^{\mathrm{i}} \mathrm{L}^{-1}$, respectively.

According to the classification of the IOBC (Hassan et al., 1994), GF-120 was placed in level 4, harmful $(>99 \%)$ at concentrations of $100,75,50,25,5,1$ and $0.8 \%$ of DRM $(96 ; 72,48,24,4.8,0.96$, and $0.77 \mathrm{mg}$ a.i. $\mathrm{L}^{-1}$, respectively). GF-120 was assigned to level

Table 1. Adult mortality of Eretmocerus paulistus Hempel at 12 and 24 hours after application of different concentrations of GL-120 under laboratory experimental conditions of $25 \pm 5{ }^{\circ} \mathrm{C}$, $30 \pm 10 \% \mathrm{RH}$ and a photoperiod of 16:8 L:D.

\begin{tabular}{lccc}
\hline & \multicolumn{2}{c}{ Mortality (\% of dead adults) ${ }^{1}$} & \\
\cline { 2 - 3 } Concentration (mg a.i. L $\left.{ }^{-1}\right)$ & 12 hours & 24 hours & Category $(24 \mathrm{~h})^{2}$ \\
\hline 96.00 & $100.00 \pm 0.00 \mathrm{a}$ & $100.00 \pm 0.00 \mathrm{a}$ & 4 \\
72.00 & $100.00 \pm 0.00 \mathrm{a}$ & $100.00 \pm 0.00 \mathrm{a}$ & 4 \\
48.00 & $100.00 \pm 0.00 \mathrm{a}$ & $100.00 \pm 0.00 \mathrm{a}$ & 4 \\
24.00 & $100.00 \pm 0.00 \mathrm{a}$ & $100.00 \pm 0.00 \mathrm{a}$ & 4 \\
4.80 & $100.00 \pm 0.00 \mathrm{a}$ & $100.00 \pm 0.00 \mathrm{a}$ & 4 \\
0.96 & $100.00 \pm 0.00 \mathrm{a}$ & $100.00 \pm 0.00 \mathrm{a}$ & 4 \\
0.77 & $93.17 \pm 2.93 \mathrm{a}$ & $100.00 \pm 0.00 \mathrm{a}$ & 4 \\
0.67 & $68.50 \pm 7.31 \mathrm{~b}$ & $97.06 \pm 2.94 \mathrm{a}$ & 3 \\
0.48 & $29.46 \pm 4.19 \mathrm{c}$ & $53.04 \pm 3.58 \mathrm{~b}$ & 2 \\
0.10 & $4.78 \pm 3.01 \mathrm{~d}$ & $30.66 \pm 4.77 \mathrm{c}$ & 2 \\
Control (distilled water) & $4.20 \pm 2.40 \mathrm{~d}$ & $20.13 \pm 2.78 \mathrm{c}$ & 1 \\
\hline
\end{tabular}

${ }^{1}$ Means followed by different letters within each column are significantly different according to Tukey's test $(\mathrm{P} \leq 0.05)$. Data are reported as the means \pm standard error.

${ }^{2}$ Categories of IOBC/WPRS (Boller according to mortality: Level 1, harmless $(<30 \%)$; level 2, slightly harmful (30-79\%); level 3, moderately harmful (80-99\%); level 4, harmful (>99\%). 
Table 2. Toxicity of spinosad on adults of Eretmocerus paulistus Hempel under laboratory experimental conditions of $25 \pm 5^{\circ} \mathrm{C}, 30 \pm 10 \% \mathrm{RH}$ and a photoperiod of $16: 8 \mathrm{~L}: \mathrm{D}$.

\begin{tabular}{lllllll}
\hline CL50 & IC 95\% & CL90 & CI 95\% & \pm S.E. & slope $X^{2}$ & d.f. \\
\hline 0.21 & $0.16-0.26$ & 0.79 & $0.63-1.08$ & $3.83 \pm 0.45$ & 72.23 & 1 \\
\hline
\end{tabular}

CI: confidence intervals. SE: Standard error. d.f.: degrees of freedom.

3 , moderately harmful (80-99\%), at a concentration of $0.7 \%$ of the DRM $\left(0.67 \mathrm{mg}\right.$ a.i. $\left.\mathrm{L}^{-1}\right)$, and to level 2 , slightly harmful (30-79\%), at the concentrations of 0.50 and $0.10 \%$ of the DRM $(0.48$ and $0.1 \mathrm{mg}$ a.i. $\mathrm{L}^{-1}$, respectively). The control, distilled water, was level 1 , harmless $(<30 \%)$.

Spinosad has been reported to be toxic to many hymenopteran parasitoids (Haseeb et al., 2004; Jones et al., 2005; Penagos et al., 2005; Schneider et al., 2004; Williams and Price, 2004; Williams et al., 2003a,b). The results obtained for the lethal concentrations are consistent with those found by Hill and Foster (2000), who determined $\mathrm{LC}_{50}=0.3$ $\mathrm{mg}$ a.i. $\mathrm{L}^{-1}$ in adults of Diadegma insulare (Cresson) (Hymenoptera, Ichneumonidae), a parasitoid of the col moth (Plutella xylostella L.) (Lepidoptera: Plutellidae) subjected to different doses of spinosad. Suh et al. (2000) obtained $\mathrm{LC}_{50}$ and $\mathrm{LC}_{90}$ values of 3.3 and $10.3 \mathrm{mg}$ a.i. $\mathrm{L}^{-1}$, respectively, for adults of Trichogramma exiguum Pinto \& Platner (Hymenoptera: Trichogrammatidae), an effective parasitoid of Helicoverpa zea (Boddie) (Lepidoptera: Noctuidae) exposed to spinosad. Penagos et al. (2005), comparing their results with other works related to the susceptibility of parasitoids to spinosad, indicated that the response to this active ingredient depends largely on the size of the insect, as those of smaller sizes were clearly more susceptible to this product. The responses to spinosad can also be variable according to the sex of individuals. The results obtained by Wang et al. (2005) confirm this finding; these authors determined $\mathrm{LC}_{50}$ values of 8.3 and $10.0 \mathrm{mg}$ a.i. $\mathrm{L}^{-1}$ for females and males, respectively, of Diachasmimorpha tryoni (Cameron) (Hymenoptera: Braconidae) and also studied parasitoid fruit flies of the genera Anastrepha Schiner and Ceratitis MacLeay (Diptera: Tephritidae). In the case of female and male Pysttalia fletcheri (Silvestri)
(Hymenoptera: Braconidae), a parasitoid of the melon fly [Bactrocera cucurbitae (Coquillet) (Diptera: Tephritidae)], the $\mathrm{LC}_{50}$ values were 17.5 and $10.0 \mathrm{mg}$ a.i. $\mathrm{L}^{-1}$, respectively.

Rogers et al. (2011) found mortalities of 12, 29, and $72 \%$ at concentrations of 12,24 , and $48 \mathrm{mg}$ i.a. $\mathrm{L}^{-1}$ of spinosad, respectively, in Aphelinus mali (Hald.) (Hymenoptera: Aphelinidae) and the parasitoid of woolly apple aphid [Eriosoma lanigerum (Hausmann)] (Hemiptera: Aphididae). These authors indicated that, at label rate $(0.048 \mathrm{~g}$ a.i. $\left.\mathrm{L}^{-1}\right)$, spinosad was "moderately to highly toxic" for adults of $A$. mali as categorized by the rating system developed by Croft (1982). The exposure of the parasitoids to one-half and one-quarter of the label rate showed a rate response, where mortality increased with increasing insecticide concentration.

Cordero et al. (2007) determined for adults of Diadegma insulare (Cresson) (Hymenoptera: Ichneumonidae) and Oomyzus sokolowskii (Kurdjumov) (Hymenoptera: Eulophidae) LC50 values of 0.346 $\mathrm{mg}$ a.i. $\mathrm{L}^{-1}$ (fiducial limits $0.034-0.904$ ) and 4.938 (fiducial limits 2.593-8.348), respectively, only a fraction $(<2 \%)$ of the actual field rate concentration. Field rate concentrations resulted in $100 \%$ mortality to both $D$. insulare and $O$. sokolowskii.

According to Luna-Cruz et al. (2011), spinosad would be located mostly in IOBC category 3 (moderately toxic, $80-99 \%$ mortality) when tested on Tamarixia triozae (Burks) (Hymenoptera: Eulophidae), a parasitoid of Bactericera cockerelli (Sulc) (Hemiptera: Triozidae) at doses of $600 \mathrm{mg}$ i.a. $\mathrm{L}^{-1}$ deposited on the leaves of tomato plants located in entomological cages.

Michaud (2003) also found high mortality for Aphytis melinus DeBach (Hymenoptera: Aphelinidae) and 
Lysiphlebus testaceipes (Cresson) (Hymenoptera: Aphidiidae) exposed to dried residues of baited spi$\operatorname{nosad}(1 \mu \mathrm{L}$ a.i. per five insects) on inert materials, and Stark et al. (2004) exposed two parasitoids, Fopius arisanus (Sonan) (Hymenoptera: Braconidae) and Psyttalia fletcheri (Silvestri) (Hymenoptera: Braconidae), to $15 \mu \mathrm{L}$ of dried residue in glass vials. A dose-mortality response of topical treatment was demonstrated by Ruiz et al. (2008) for the parasitoid Diachasmimorpha longicaudata (Ashmead) (Hymenoptera: Braconidae), which was also greatly affected in contact with dried residues and when the field rate was ingested.

Spinosad was classified, based on the IOBC toxicity ratings, as class 4 (harmful, $>99 \%$ reduction) because of its high direct mortality on the parasitized mummies of Eretmocerus mundus (Mercet) (Hymenoptera: Aphelinidae) when sprayed with a concentration of $120.0 \mathrm{mg}$ a.i. L $\mathrm{L}^{-1}$ (Fernández et al., 2010).

\section{E. paulistus Feeding (no-choice and residual tests)}

The analysis of variance showed significant effects of the concentration of GF-120 ( F = 93.40, d.f. $=2,27, \mathrm{P} \leq 0.001)$, in times of dry residues
$(\mathrm{F}=33.24$, d.f. $=2,27, \mathrm{P} \leq 0.001)$ and in the interaction between both factors $(\mathrm{F}=18.47$, d.f. $=4$, $27, \mathrm{P} \leq 0.001)$. The highest mortalities $(>90 \%)$ were obtained with residues of 1 hour drying time with concentrations of $25 \%$ or $40 \%$ of the recommended dose (Table 3). When the drying time was longer (48 and $96 \mathrm{~h}$ ), mortalities were between 60 and $87 \%$.

According to IOBC classification, GF-120 was level 4, harmful (>99\%) in the combination of $25 \%$ DRM (24 mg a.i. $\left.\mathrm{L}^{-1}\right)$ x $1 \mathrm{~h}$ (residue time). Level 3, moderately harmful (80-99\%), was achieved in the combinations of $40 \%$ DRM (38.4 mg a.i. $\left.\mathrm{L}^{-1}\right) \times 1 \mathrm{~h}$ and $40 \%$ D.R.M. x 48 h, and level 2, slightly harmful (30-79\%), was achieved in the combinations of $25 \%$ DRM $\times 48 \mathrm{~h}, 25 \%$ DRM $\times 96 \mathrm{~h}$ and $40 \% \mathrm{DRM} \times 96 \mathrm{~h}$. Level 1 , harmless $(<30 \%)$, was displayed by the control (distilled water) at all residue times.

Studies on spinosad intake, using GF-120 in doses recommended for the control of fruit flies as a way to study the effect on beneficial organisms, have shown considerable variation according to the species and doses tested. Ruiz et al. (2008) subjected adults of the braconid Diachasmimorpha longicaudata (Ashmead) to mixtures of GF-120

Table 3. Categorization of mortality on Eretmocerus paulistus adults according to the IOBC after $12 \mathrm{~h}$ of exposure to different doses of GF-120 and periods of persistence.

\begin{tabular}{lccc}
\hline Treatments & $\begin{array}{c}\text { Residue time } \\
\text { (hours) }\end{array}$ & $\begin{array}{c}\text { Mortality } \\
(\%) \pm \text { S.E. }\end{array}$ & Category $^{2}$ \\
\hline GF 120 at $25 \%$ & 1 & $100.00 \pm 0.00 \mathrm{a}$ & 4 \\
GF 120 at $40 \%$ & 1 & $91.61 \pm 2.80 \mathrm{~b}$ & 3 \\
GF 120 at $25 \%$ & 48 & $73.82 \pm 3.68 \mathrm{~cd}$ & 2 \\
GF 120 at $40 \%$ & 48 & $87.02 \pm 0.77 \mathrm{bc}$ & 3 \\
GF 120 at $25 \%$ & 96 & $68.55 \pm 5.09 \mathrm{~cd}$ & 2 \\
GF 120 at $40 \%$ & 96 & $60.77 \pm 0.72 \mathrm{~d}$ & 2 \\
Control (distilled water) & 1 & $5.64 \pm 2.26 \mathrm{e}$ & 1 \\
Control (distilled water) & 48 & $2.28 \pm 1.45 \mathrm{e}$ & 1 \\
Control (distilled water) & 96 & $9.40 \pm 1.04 \mathrm{e}$ & 1 \\
\hline
\end{tabular}

${ }^{1}$ Means followed by the same letter in each column are not significantly different according to Tukey's Test $(\mathrm{P} \leq 0.05)$.

${ }^{2}$ Categories of IOBC according to mortality obtained: Level 1, harmless ( $\left.<30 \%\right)$; level 2 , slightly harmful (30-79\%); level 3, moderately harmful (80-99\%); level 4, harmful (99\%). 
at $80 \mathrm{mg}$ a.i. $\mathrm{kg}^{-1}$ and honey (v/v), a simulation of hemipteran honeydew contamination with attractant. The mortality and fertility results obtained indicate that this route of entry is detrimental to this species. However, these authors noted that parasitoids were rarely observed feeding directly on the bait mixed with honey, which suggests that some components would be repellent to this species, but there was an incidence by way of contact. Similar results were obtained by Michaud (2003), who exposed adults of A. melinus and L. testaceipes to applications of $1 \mu \mathrm{L}$ of GF-120 and honey. The author obtained significant mortality within the first $24 \mathrm{~h}$ of evaluation, reaching between 88 and $80 \%$ for $A$. melinus and L. testaceipes, respectively.

Vargas et al. (2002) determined that Fopius arisanus (Sonan) (Hymenoptera: Braconidae), a parasitoid of fruit flies, does not feed on mixtures of protein baits of GF-120 intended for the control of tephritids, which provide an efficient control for the pest, with minimal effect on biological control. Wang et al. (2005) conducted feeding trials on the same braconid; these tests included three different types of food: GF-120 at 80 ppm, 33\% honey solution and distilled water. These authors concluded that this species does not feed directly on GF-120, suggesting that mortality obtained was a result of a direct contact between the insect and the product.

\section{Residual test}

In laboratory tests, Suma et al. (2009) determined that fresh residues of spinosyn at $480 \mathrm{~g} \mathrm{~L}^{-1}$ active ingredient caused $100 \%$ mortality in A. melinus, Coccophagus lycimnia Walker (Hymenoptera: Aphelinidae), and Leptomastix dactylopii Howard (Hymenoptera: Encyrtidae) in $24 \mathrm{~h}$. These same authors, in semi-field trials with L. dactylopii, observed a reduction in mortality, while the rate of parasitism and survival in females was not affected.

According to Ruiz et al. (2008), mortality in parasitoids of considerable size, such as $D$. longicaudata, is directly related to the dose of this product. However, the effect of walking on spinosyn-treated surfaces for long periods of time, regardless of dose (20, 40 and $80 \mathrm{mg}$ of a.i. $\mathrm{kg}^{-1}$ ), resulted in high mortality and a reduction of survival time for this species compared with the control, demonstrating the contact toxicity of this insecticide. In addition, the authors noted that exposures longer than $10 \mathrm{~d}$ of this braconid to the spinosyn residues on mango leaves caused a reduction in the progeny and net fertility of females.

Medina et al. (2008) evaluated the toxicity and kinetics of spinosad in adults of Hyposoter didymator (Thunberg) (Hymenoptera: Ichneumonidae). This study found that insects accumulate relatively small amounts of insecticide in the body but that half of the active ingredient is found in the ovary. This finding is explained by the large amount of hemolymph that is directed to that zone for the production of eggs and has a direct relation to the sub-lethal effects of this insecticide on the reproductive parameters of this species.

The survival of female wasps of Anaphes iole Girault (Hymenoptera: Mymaridae) exposed to field-weathered residues of spinosad on cotton leaves resulted in $<3 \%$ survival (its persistence was $>11$ days) at a concentration of $0.1 \mathrm{~kg}$ a.i. ha $^{-1}$ (Williams et al., 2003a).

While spinosad proved highly harmful to adults of E. paulistus under the conditions of this study, there is a need to develop new studies in more adverse conditions, such as semi-field and field conditions, less susceptible life stages of the parasitoid, or under the action of light and temperature on bait residues, to understand the insect-pesticide relationship more extensively.

Spinosad concentrations of $0.48 \mathrm{mg}$ a.i. $\mathrm{L}^{-1}$ induced significant mortality of E. paulistus adults at 12 and $24 \mathrm{~h}$ under laboratory conditions. The route of exposure to spinosad by surface contact caused significant mortality of E. paulistus. Spinosad residues with 1, 48 and $96 \mathrm{~h}$ of preparation resulted in high mortality of E paulistus adults. It 
should be considered that the impact in relation to the behavior of this insecticide on biocontrol agents, both in different weather conditions and at different application methods (spray on patch, baited tablets and bait stations), are still unknown in most places where is applied. Therefore, the development of field experience is essential to obtain more information about the effects of this natural active ingredient on populations of biocontrol agents without confinement and its relationship with the eventual resurgence of pest species populations.

\section{Resumen}

V. Tello, L. Días y M. Sánchez. 2013. Side effects of natural pesticide spinosad (GF-120 formulation) on Eretmocerus paulistus parasitoid of the whitefly Aleurothrixus floccosus under laboratory conditions. Cien. Inv. Agr. 40(2): 407-417. Se evaluó el efecto colateral del insecticida GF-120 NF Naturalyte 0.02 CB® sobre adultos de Eretmocerus paulistus, parasitoide de Aleurothrixus floccosus en cítricos en el norte de Chile. Se determinó la CL50 y CL90, aplicando el insecticida mediante torre Potter, en dosis decreciente desde 0,96 hasta 0,1 mg a.i. $\mathrm{L}^{-1}$ (correspondientes al $1 \%$ y al $0,1 \%$ de la dosis recomendada, respectivamente). Los resultados correspondientes a las $24 \mathrm{~h}$ se ajustaron a un modelo Probit y se estimaron en 0,21 y 0,79 mg i.a. L L $^{-1}$ (CL50 y CL90, respectivamente). En ensayos de alimentación y evaluación del efecto tóxico de residuos secos de GF-120, se determinó que la mayor mortalidad (100\%) se obtuvo con una combinación de $24,0 \mathrm{mg}$ i.a. $\mathrm{L}^{-1} \times$ residuos de 1 hora. Residuos de $96 \mathrm{~h}$ (4 días), con concentraciones de 38,4 ó 24,0 mg i.a. $\mathrm{L}^{-1}$, produjeron mortalidades superiores al 60\%. De acuerdo a la clasificación de la IOBC (International Organization for Biological and Integrated Control of Noxious Animals and Plants), la concentración recomendada por fabricante de $96 \mathrm{mg}$ i.a. $\mathrm{L}^{-1}$ fue de nivel 4 (perjudicial, >99\%), lo mismo ocurrió con concentraciones de GF-120 que variaron entre 0,77 a $72 \mathrm{mg}$ i.a. $\mathrm{L}^{-1}$. Los residuos de GF-120, aplicados sobre superficies inertes fueron dañino para E. paulistus, con altas tasa de mortalidad bajo condiciones de laboratorio. Se requieren estudios de campo para validar estos resultados evaluando poblaciones del parasitoide en áreas tratadas y no tratadas con este insecticida.

Palabras clave: bioensayos, efectos colaterales, efecto residual, insectos parasitoides, pesticida natural, toxicidad.

\section{References}

Abbott, W.S. 1925. A method for computing the effectives of an insecticide. Journal of Economic Entomology. 18:265 - 267.

Araya, J., M. Araya, and M.A. Guerrero. 2010. Effects of some insecticides applied in sublethal concentrations on the survival and longevity of Aphidius ervi (Haliday) (Hymenoptera: Aphidiidae) adults. Chilean Journal of Agricultural Research 70:221-227.
Biondi, A., V. Mommaerts, G. Smagghe, E. Viñuela, L. Zappalà, and N. Desneux. 2012. The non-target impact of spinosyns on beneficial arthropods. Pest Management Science 68:1523-1536.

Cisneros, J., D. Goulson, L.C. Derwent, D.I. Penagos, O. Hernández, and T. Williams. 2002. Toxic effects of spinosad on predatory insects. Biological Control 23:156-163.

Cordero, R.J., J.R. Bloomquist, and T.P. Kuhar. 2007. Susceptibility of two diamondback moth parasit- 
oids, Diadegma insulare (Cresson) (Hymenoptera: Ichneumonidae) and Oomyzus sokolowskii (Kurdjumov) (Hymenoptera: Eulophidae), to selected commercial insecticides. Biological Control 42:48-54.

Croft, B.A. 1982. Arthropod resistance to insecticides: a key to pest control failures and successes on North American apple orchards. Entomologia Experimentalis et Applicata 31: 88-110.

Dayan, F., C. Cantrell, and S. Duke. 2009. Natural products in crop protection. Bioorganic \& Medicinal Chemistry Letters 17:4022-4034.

Delaplane, KS. 2000. Pesticide usage in the United States: history, benefits, risks, and trends. Cooperative Extension Service/The University of Georgia College of Agricultural and Environmental Sciences. Bulletin 1121. Available online at http://pubs.caes.uga.edu/caespubs/pubs/ PDF/B1121.pdf (Website accessed: January 6, 2013).

Fernández, M., P. Medina, P. Del Estal, and E. Viñuela. 2010. Testing side-effects of pesticides on the most protected life stage of Eretmocerus mundus (Mercet) (Hymenoptera, Aphelinidae), parasitoid of the whitefly Bemisia tabaci (Gennadius) (Hemiptera, Aleyrodidae) in the laboratory. IOBC/ WPRS Bulletin 55:101-107.

Flores, A., G. Silva, M. Tapia, and P. Casals. 2007. Susceptibilidad de Tetranychus urticae Koch (Acari: Tetranychidae) colectada en Primula obconica Hance y Convolvulus arvensis L. a acaricidas. Agricultura Técnica (Chile) 67:219-224.

Hassan, S.A., F. Bigler, H. Bogenschütz, E. Boller, J. Brun, J.N.M. Calis, C. Duso, A. Grove, N. Helyer, U. Heimbach, J. Coremans-Pelseneer, H. Hokkanen, G.B. Lewis, F. Mansour, L. Moreth, L. Polgar, L. Samsoe-Petersen, B. Sauphanor, A. Stàubli, G. Sterk, M. Van De Veire, G. Viggiani, and H. Vogt. 1994. Results of the Sixth Joint Pesticide Testing Programme of the IOBC/WPRSWorking Group "Pesticides and Beneficial Organisms". Entomophaga 39:107-119.

Haseeb, M., T.X. Liu, T.X., and W.A. Jones. 2004. Effects of selected insecticides on Cotesia plutellae, endoparasitoid of Plutella xylostella.BioControl 49:33-46.
Hill, T.A., and R.E. Foster. 2000. Effect of Insecticides on the diamondback moth (Lepidoptera: Plutellidae) and its parasitoid Diadegma insulare (Hymenoptera: Ichneumonidae). Horticultural Entomology 93:763- 768 .

Iannacone, J., and G. Lamas. 2003. Efectos toxicológicos del nim, rotenona y cartap, sobre tres microavispas parasitoides agrícolas en el Perú. Boletín de Sanidad Vegetal-Plagas 29:123-142.

Ishaaya, I., G. Lebedev, M. Ghanim, and A.R. Horowitz. 2011. Biorational control of arthropods pests with emphasis on the use of the chitin synthesis inhibitor novaluron. Pestycydy/Pesticides. 1(4):17-22.

James, J.R., B.G. Tweedy, and L.C. Newby. 1993. Efforts by industry to improve the environmental safety of pesticides. Annual Review of Phytopathology 31:423-439.

Jones, T., C. Scott-Dupree, R. Harris, L. Shipp, and B. Harris. 2005. The efficacy of spinosad against the western flower thrips, Frankliniella occidentalis, and its impact on associated biological control agents on greenhouse cucumbers in southern Ontario. Pest Management Science 61:179-185.

Kirst, H.A. 2010. The spinosyn family of insecticides: realizing the potential of natural products research. The Journal of Antibiotics 63:101-111.

Lagunes, A., and J. Villanueva. 1999. Toxicología y manejo de insecticidas. Colegio de Postgraduados. Montecillo. México. 264 pp.

Luna-Cruz, A., J.R. Lomeli-Flores, E. RodríguezLeyva, L. Ortega-Arenas, and A. Huerta-de la Peña. 2011. Toxicidad de cuatro insecticidas sobre Tamarixia triozae (Burks) (Hymenoptera: Eulophidae) y su hospedero Bactericera cockerelli (Sulc) (Hemiptera: Triozidae). Acta Zoológica Mexicana 27:509-526.

Mangan, R., D. Moreno, and G. Thompson. 2006. Bait dilution, spinosad concentration, and efficacy of GF-120 based fruit fly sprays. Crop Protection 25:125-133.

Martínez, J.L., M. Vidal, J. González, A. Belmonte, and A. Garrido. 2004. Estudio de la contaminación por pesticidas en aguas ambientales de la provincia de Almería. Ecosistemas 13(3):30-38. 
Medina, P., J. Morales, G. Smagghe ,and E. Viñuela. 2008. Toxicity and kinetics of spinosad in different developmental stages of the endoparasitoid Hyposoter didymator (Hymenoptera: Ichneumonidae) and its host Spodoptera littoralis larvae (Lepidoptera: Noctuidae). BioControl 53:569-578.

Michaud, J.P. 2003. Toxicity of fruit fly baits to beneficial insects in citrus. Journal of Insect Science 3:1-9.

Miles, J.M., A. Alix, Ch. Bourgouin, and S. Schmitzer. 2011. Effects of spinosad on honey bees (Apis mellifera): Findings from over ten years of testing and commercial use. 11th International Symposium of the ICP-BR Bee Protection Group, Wageningen (The Netherlands). p. 107-114.

Orr, N., A. Shaffner, K. Richey, and G. Crouse. 2009. Novel mode of action of spinosad: Receptor binding studies demonstrating lack of interaction with known insecticidal target sites. Pesticide Biochemistry and Physiology 95:1-5.

Penagos, DI., J. Cisneros, O. Hernández, and T. Williams. 2005. Lethal and sublethal effects of the naturally derived insecticide spinosad on parasitoids of Spodoptera frugiperda (Lepidoptera: Noctuidae). Biocontrol Science and Technology 15:81-95.

Pérlite, A., C. Caprini, D. Alves, G. Pimentel, V. Dahlström, and J. Marlei. 2009. Occupational exposure of farm workers to pesticides: Biochemical parameters and evaluation of genotoxiticy. Environment International 35:273-278.

Pozo, P. 2010. Susceptibilidad a insecticidas de diferentes grupos químicos en poblaciones de Tuta absoluta (Meyrick). Memoria de Título. Facultad de Ciencias Agrarias, Universidad Austral de Chile. Valdivia, Chile. 44 pp.

Rogers, D.J., Sharma, N., Stretton, D.C., and Walker, J.T.S. 2011. Toxicity of pesticides to Aphelinus mali, the parasitoid of woolly apple aphid. New Zealand Plant Protection 64:235-240.

Rojas, G. 2011. Efecto del azufre, aceite y spinosad sobre Cryptolaemus montrouzieri Mulsant y Pseudaphycus flavidulus (Brethés) bajo condiciones de laboratorio. Available online at http:// tesis.uchile.cl/handle/2250/111428 (Website accessed: January 4, 2013).

Rose, R.L., E. Hodgson, and R.M. Roe. 1999. Pesticides. In: Hans Marquardt, S.G. Schäfer, R. O. McClellan and F. Welsch (eds.). Toxicology. Academic Press. p. 663-698.

Ruiz, L., S. Flores, J. Cancino, J. Arredondo, J. Valle, F. Díaz-Fleischer, and T. Williams. 2008. Lethal and sublethal effects of spinosad-based GF-120 bait on the tephritid parasitoid Diachasmimorpha longicaudata (Hymenoptera: Braconidae). BioControl 44:296-304.

Salazar, E., and J. Araya. 2001. Respuesta de la polilla del tomate Tuta absoluta (Meyrick), a insecticidas en Arica. Agricultura Técnica (Chile) 61:429-435.

Schmutterer, H. 1990. Properties and potential of natural pesticides from the Neem tree, Azadirachta indica. Annual Review of Entomology 35:271-297.

Schneider, M.I., G. Smagghe, S. Pineda, and E. Vinuela. 2004. Action of insect growth regulator insecticides and spinosad on life history parameters and absorption in third-instar larvae of the endoparasitoid Hyposoter didymator. Biological Control 31:189-198.

Suh, C.P., D.B. Orr, and J.W. Van Duyn. 2000. Effect of Insecticides on Trichogramma exiguum (Trichogrammatidae: Hymenoptera) Preimaginal Development and Adult Survival. Journal of Economic Entomology 93:577-583.

Stark, J.D., R. Vargas, and N. Miller. 2004. Toxicity of spinosad in protein bait to three economically important tephritid fruit fly species (Diptera: Tephritidae) and their parasitoids (Hymenoptera: Braconidae). Journal of Economic Entomology 97:911-915.

Studebaker, GL., and T.J. Kring. 2003. Effects of insecticides on Orius insidiosus (hemiptera: Anthocoridae), measured by field, greenhouse and Petri dish bioassays. Florida Entomology 86:178-185.

Suma, P., L. Zappalà, G. Mazzeo, and G. Siscaro. 2009. Lethal and subletal effects of insecticides on natural enemies of citrus scale pest. BioControl 54:651-661. 
Thomas, D.B. and R.L. Mangan. 2005. Nontarget impact of spinosad GF-120 bait sprays for control of the Mexican Fruit Fly (Diptera: Tephritidae) in Texas citrus. Journal of Economic Entomology 98:1950-1956.

Thomson, G.D., R. Dutton, T.C. Sparks. 2000. Spinosad-a case study: an example from a natural products discovery programme. Pest Management Science 56:696-702.

Ulloa, A., T. Curkovic, and J. Araya. 2006. Toxicidad oral de seis insecticidas en larvas de Vespula germanica (F.) en laboratorio. Agricultura Técnica (Chile) 66:133-140.

Vargas, R., and A. Ubillo. 2001. Toxicidad de pesticidas sobre enemigos naturales de plagas agrícolas. Agricultura Técnica (Chile) 61:35-41.

Vargas, R., and A. Ubillo. 2005. Susceptibilidad de Frankliniella occidentalis (Thysanoptera:Thripidae) a insecticidas en la zona central de Chile. Agricultura Técnica (Chile) 65(4): 437-441.

Vargas, R., N. Miller, and R. Prokopy. 2002. Attraction and feeding responses of Mediterranean fruit fly and a natural enemy to protein baits laced with two novel toxins, phloxine B and spinosad. Entomologia Experimentalis et Applicata 102:273-282.

Viggiani, G., and A. Tranfaglia. 1978. A method for laboratory test of side effects of pesticides on Leptomastix dactylopii (How.) (Hym. Encyrtidae). Bollettino del Laboratorio di Entomologia Agraria Filippo Silvestri, Portici 35:8-15.

Wang, X., E. Jarjees, B. McGraw, A. Bokonon, R. Messing, and M. Johnson. 2005. Effects of spinosad-based fruit fly bait GF-120 on teph- ritid fruit fly and aphid parasitoids. BioControl 35:155-162.

Waterfield, G., and D. Zilberman. 2012. Pest management in food systems: An economic perspective. Annual Review of Environment and Resources 37:223-245.

Williams, L., and L.D. Price. 2004. A space-efficient contact toxicity bioassay for minute Hymenoptera, used to test the effects of novel and conventional insecticides on the egg parasitoids Anaphes iole and Trichogramma pretiosum. BioControl 49:163-185.

Williams, T., Valle, J., and Viñuela, E., 2003a. Is the naturally derived insecticide Spinosad compatible with insect natural enemies? Biocontrol Science and Technology 13:459-475.

Williams, L., Price, L.D., and Manrique, V. 2003 b. Toxicity of field-weathered insecticide residues to Anaphes iole (Hymenoptera: Mymaridae), an egg parasitoid of Lygus lineolaris (Heteroptera: Miridae), and implications for inundative biological control in cotton. Biological Control 26:217-223.

Yee, W.L., and D.G. Alston. 2012. Control of Rhagoletis indifferens using thiamethoxan and spinosad baits under external fly pressure and its relation to rapidity of kill and residual bait activity. Crop Protection 41:17-23.

Young, H.P., W.D. Bailey, and R.M. Roe. 2003. Spinosyd selection of a laboratory strain of the tobacco budworm, Heliothis virescens (Lepidoptera: Noctuidae), and characterization of resistance. Crop Protection 22:265-273.

Zar, J.H. 2006. Biostatistical analysis. PrenticeHall Inc. 5 edition, Englewood Cliffs, New Jersey,USA. 960 pp. 
